\title{
Sprachmischung: relação entre sujeito, língua e história
}

\author{
Vejane Gaelzer ${ }^{11}$
}

Résumé: nous cherchons analyser, dans cette recherche, les relations de contradiction qui entrent en jeu entre les discours et les pratiques du gouvernement de l'État Nouveau sur les questions de nationalité et, au même temps, les discours des immigrants allemands et leurs descendants, impliquant la mémoire discursive, par qui se dégage de la reconnaissance du groupe germano-brésiliens et l'interdiction du sujet pour la langue. Pour réfléchir à ces questions nous travaillons avec les notions théoriques de Bakhtine (2004), Pecheux (1997) et Orlandi (2007). La langue est un élément essentiel dans la construction du imaginaire d'identification des immigrants comme un groupe et cet imaginaire vient de la mémoire discursife quand ils parlent de si. Et c'est par la langue que le gouvernement «varguista» cherche à introduire la construction imaginaire de l'être brésilien. Si, d'un côté la langue nationale est une attestation juridique de l'être brésilien conforme au projet de nationalisation du gouvernement Vargas, d'un autre côté, elle montre l'oubli de la langue maternelle des immigrants. Donc, l'interdiction officielle au cours de l'État Nouveau apporte des conséquences à la vie des immigrants et intervient directement sur leurs pratiques sociales quotidiennes. Cette interdiction résonne encore à la mémoire sociale de ce groupe. Malgré l'effort et l'implémentation juridique de l'État, la langue maternelle des immigrants a survécu à sa prohibition et elle continue vivante dans les pratiques sociales dans l'espace privé de quelques communautés. Il s'agit de une langue typique, e mélange du dialecte allemand avec la langue portugaise: La Sprachmischung. Le corpus discoursif est composé des rapports des enfants d'immigrants allemands du Rio Grande do Sul qui se développent dans leurs composantes sociales imaginaires reliant à leurs ancêtres. Ainsi, à base de l'analyse discursife du corpus, nous percevons la relation des sujet avec la langue et la façon dont ils reconnaissent eux-mêmes a partir de cette langue, como sujets allemands-brésiliens.

Mots-clé : construction imaginaire, élément symbolique d'identification, allemands-brésiliens, processus discursif, pratiques sociales.

1 Professora do Instituto Federal de Educação, Ciência e Tecnologia Farroupilha. Doutora em Letras pela UFRGS. 
Resumo: nesta pesquisa, buscamos analisar as relações de contradição que entram em jogo entre os discursos e as práticas do governo do Estado Novo sobre as questões de nacionalidade e, ao mesmo tempo, os discursos de imigrantes alemães e seus descendentes, envolvendo a memória discursiva, pela qual emerge o reconhecimento ao grupo de alemães-brasileiros e a interdição do sujeito pela língua. Para refletirmos sobre essas questões trabalhamos com o aporte teórico de Bakhtin (2004), de Pêcheux (1997) e de Orlandi (2007). A língua é um elemento essencial na construção do imaginário de identificação dos imigrantes como grupo e esse imaginário aparece na memória discursiva ao falarem de si. E é por meio da língua que o governo varguista procura instituir a construção imaginária de brasilidade. Se por um lado, a língua nacional é um atestado jurídico de brasilidade, conforme o projeto de nacionalização do governo varguista, por outro lado, ela traz a injunção ao esquecimento da língua materna dos imigrantes. Portanto, a interdição oficial durante o Estado Novo traz consequências para a vida dos imigrantes e interfere diretamente nas suas práticas sociais diárias e essa interdição ainda hoje ecoa na memória social desse grupo. Apesar do esforço e da implementação jurídica do Estado, a língua materna dos imigrantes sobreviveu à proibição e continua viva nas práticas sociais no espaço privado familiar em algumas comunidades. Trata-se de uma língua típica, a mistura do dialeto alemão com a língua Portuguesa: a Sprachmischung. O corpus discursivo é composto por relatos de filhos de imigrantes alemães do Rio Grande do Sul, que cultivam no seu imaginário social elementos de ligação com seus antepassados. Assim, com base na análise discursiva do corpus, percebemos a relação dos sujeitos com a língua e o modo como ele se reconhece a partir dela, como sujeitos alemães-brasileiros.

Palavras-chave: construção imaginária, elemento simbólico de identificação, alemães-brasileiros, processo discursivo, práticas sociais.

\section{Introdução}

Este artigo é resultado de reflexões posteriores elaboradas em torno do tema desenvolvido na Tese de Doutorado, intitulada "Construções imaginárias e memória discursiva de imigrantes Alemães no Rio Grande do Sul”. Nesta pesquisa, foram elaboradas reflexões acerca do processo da Sprachmischung, pautado nos conceitos de sujeito e de língua, desenvolvidos por Mikhail Bakhtin (2004) e por Michel Pêcheux (1997). Cabe destacarmos que ao trabalharmos com a concepção de Sprachmischung, trouxemos as questões do funcionamento da língua a partir das práticas sociais dos sujeitos imigrantes alemães e seus descendentes. Deste modo, as sequências discursivas desses sujeitos são fundamentais para percebermos que a língua que os constitui e os torna sujeito é a Sprachmischung e nela eles se reconhecem e compartilham dos mesmos costumes e culturas, cujo reconhecimento emerge na memória discursiva, ao falarem e de si e do seu grupo.

Nesta perspectiva, na Sprachmischung, temos uma língua fluida (ORLANDI, 2002) que se materializa nas práticas sociais das Gemeinde (comunidades) e que se preserva de geração em geração. Assim, a Sprachmischung, é uma forma de reconhecimento e remete a um sentimento de pertencimento que faz parte da identificação do grupo de imigrantes e seus descendentes e que vive no imaginário social que os constitui. 
Ao tratarmos das questões pertinentes a Sprachmischung, observamos a relação entre sujeito, língua e história. Neste viés, existem vários elementos que contribuem para o processo da Sprachmischung, entre eles, destacamos o sujeito e as condições históricas, nas quais ele está inserido. Deste modo, nesta pesquisa, adotamos a concepção de sujeito interpelado de Pêcheux (1997) que passa pela língua, pela história e pela ideologia. De acordo com o autor, a ideologia e inconsciente são constitutivos do sujeito, ambos funcionam sob "um tecido de evidências subjetivas"2. Trata-se da evidência do sujeito como único e insubstituível e idêntico a si mesmo, sob a ilusão de ser livre e dono do seu discurso. Entretanto, nesta evidência, temos mascarada a interpelação do sujeito. Isso equivale dizer que o sujeito torna-se sujeito pela submissão à língua nas práticas sociais em que ele está inserido. Assim, não podemos falar de sujeito, sem falar de língua, esta inserida nas práticas sociais nos modos como os processos de subjetivação se produzem. Segundo as reflexões do autor, as formas de subjetivação dos sujeitos se dão pela dimensão histórica e ideológica, dado que o sujeito não é detentor e origem do seu discurso, mas é atravessado e constituído, posicionando-se a partir de redes discursivas. Para tanto, o sentido não está preso e fixo às palavras, como se fosse apenas um e dele derivassem outros, antes os sentidos são determinados sócio-historicamente.

Ao nos debruçarmos sobre os sujeitos imigrantes alemães e seus descendentes, percebemos que a construção imaginária desses sujeitos não é algo pronto e acabado, antes está em constante movimento a partir do olhar lançado sobre eles, conforme as condições de produção sob as evidências subjetivas. Para Pêcheux (1997), o que oculta essa evidência é o fato de que o "o sujeito é desde sempre "um indivíduo interpelado em sujeito "'’3. Deste modo, na evidência do sujeito e na evidência do sentido, compreende-se que a origem da subjetividade do sujeito e da sua identidade parece estar no próprio sujeito e que os efeitos de sentido parecem claros e transparentes, de modo que o sujeito parece ter controle total sobre si e sobre aquilo que enuncia. No entanto, Pêcheux (id.) nos mostra que a origem da subjetividade e da identidade não estão no sujeito, mas nas condições sócio-econômicas, em que ele se inscreve e que o interpelam, transformam e identificam esse sujeito. Segundo o autor, a evidência do sujeito, como resultado de um processo que ele chama de "interpelação-identificação".

Ao refletirmos sobre o processo de interpelação-identificação dos imigrantes alemães, temos que considerar os acontecimentos históricos das décadas de 1930 e 1940, porque o discurso do governo de Getúlio Vargas intervém diretamente nas práticas sociais desses sujeitos. Esses acontecimentos, aos quais nos referimos, não se tratam apenas das formas xenofóbicas através das quais os discursos da Formação Discursiva Governo Vargas $(\mathrm{FDGV})^{4}$ intervém nas práticas sociais desses sujeitos, mas também da forma que esses

2 PÊCHEUX, Michel. Semântica e discurso: uma crítica à afirmação do óbvio. Campinas: Ed. Unicamp, 1997, p.153.

3 ibidem, p. 155 .

4 Ao nos referirmos à FDGV, estamos tratando dos acontecimentos históricos das décadas de 1930 e 1940, no período do Estado Novo, em que o governo Vargas implanta o Plano de Nacionalização. Para isso, o governo adota diversas medidas, entre elas, o Decreto-Lei n ${ }^{\circ} 1.545$, expedido em 25 de agosto de 1939, cujo conteúdo faz menção à regulamentação da língua Portuguesa como língua nacional e institui a proibição de qualquer língua estrangeira, tanto em esfera pública, como privada. Essa medida afeta diretamente os imigrantes e seus descendentes, uma vez que eles não podiam mais usar a sua língua materna, a língua Alemã, somente a nacional, a qual pouquíssimos sabiam. A partir desse decreto são adotadas algumas medidas que buscam a "adaptação" 


\section{Conexão Letras}

discursos mantêm relações com discursos dos próprios imigrantes e deles constituem seus lugares sociais. Muitas vezes, os imigrantes procuram refutar, sob a forma de resistência nas suas práticas sociais diárias, esses olhares que constroem imaginário sobre eles e como esses discursos perpassam a construção imaginária que fazem de si. Conforme Pêcheux (1997), apesar do sujeito ser dado como evidente e dono do seu discurso, o sujeito é um sujeito assujeitado e os sentidos são construídos no interior de cada FD.

Isso significa que as mesmas palavras podem assumir efeitos de sentido diferentes ao se inscrevem na Formação Discursiva Imigrantes Alemães (FDIA) ${ }^{5}$ ou na FDGV. Nesta ótica, ao buscarmos o sentido das palavras, precisamos verificar em qual FD estas palavras estão inscritas. Portanto, ao nos referirmos aos imigrantes alemães e seus descendentes, precisamos considerar a FDIA que a partir dela as palavras significam, determinando o que pode e deve ser dito, assim como aquilo que não deve e não pode ser dito (COURTINE, 2009). Ademais, é a FD que fornece as evidências pelas quais os sujeitos se reconhecem e, ao mesmo tempo, produzem construções imaginárias de si e dos outros.

Dessa forma, com intuito de analisar como alguns saberes são construídos, traremos, a seguir, uma sequência discursiva de uma senhora, neta de imigrantes alemães. Seus avós chegaram ao Brasil em meados do século XIX e, como muitos outros imigrantes, se instalaram fora da região central da imigração. A senhora ainda reside na região da cidade de Tuparendi, que se localiza em torno de $520 \mathrm{~km}$ da região berço da imigração, região de São Leopoldo e Novo Hamburgo. Segundo ela, seus pais lhes contavam que era muito importante ensinar as crianças a falar a língua Alemã para se manterem unidos e foi isso que ela fez. Seus filhos falam a língua de seus avós.

Sd1: alles war auf Deutsch bei uns zuerst. Mit die Nachbarn da war alles Deutsch, mia konnten garnicht brasilianisch. Geburstags gefeiert, die Großmutter hatte immer viel Gebäcks gehabt, alles auf dem Tisch. Das gute Gebäcks Von Deutschland. Die ganze Familie hat sich getroffen bei der Großmutter, ich weiß es waren grosse Feste ${ }^{\text {. }}$

Se considerarmos que entram em uma Formação Discursiva os saberes constituídos a partir de uma conjuntura dada, então podemos a partir de Sd1 pensar algumas questões sobre a construção dos saberes da FDIA. Isso equivale dizer que alguns ditos são significados e assimilados, enquanto outros, excluídos. Deste modo, ao observarmos a Sd1 percebemos alguns saberes que permeiam a construção de elementos simbólicos desse grupo, a saber: a união entre a família, "die ganze Familie hat sich getroffen bei der Großmutter" (toda família se encontrava na casa da minha avó); a preservação dos costumes trazidos da Alemanha, como o fazer bolachas caseiras ${ }^{7}$.

dos imigrantes e seus descendentes.

5 Ao trabalharmos com a FDIA, estamos nos referindo aos saberes dos imigrantes alemães trazidos do seu país de origem e que foram adaptados em solo tropical. Contudo, é pertinente destacarmos que eles tentaram reproduzir o modo de vida que levavam e esse modo está pautado em três pilares, que constituem as suas comunidades: família, igreja e escola.

6 No nosso convívio, primeiramente, era tudo em alemão. Com os vizinhos era tudo em alemão, nós nem sabíamos o português. Comemorações de aniversário, a minha avó sempre tinha muitas bolachas e quitutes, tudo era colocado na mesa. Esses quitutes trouxeram da Alemanha. Toda família se encontrava na casa da minha avó, eu sei eram grandes festas [a tradução é nossa].

7 Esse ritual ainda hoje é conservado nas famílias e muitas receitas são passadas de geração a geração. Segundo os rituais alemães, esse é um momento de união, de celebrar a comunhão, os laços afetivos e familiares. Como ressalta a tradição, a dona de casa sabe do ritual e passa-o para as suas filhas, pois as bolachas feitas manteiga ou de mel e xarope enchem a casa inteira com seu delicioso aroma. As bolachas são cortadas em formatos de 
Além dos momentos de confraternização que os uniam, a língua também desempenhou a função de estabelecer vínculos sociais com outras pessoas. Dentro do espaço da comunidade tudo girava em torno da língua Alemã, como nos relata a senhora "alles war bei uns zuerst Deutsch. Mit die Nachbarn da war alles Deutsch, mia konnten garnicht brasilianisch" (no nosso convívio, primeiramente, era tudo em alemão. Com os vizinhos era tudo em alemão, nós não sabiamos português). Cabe destacarmos que nessa sequência discursiva temos presente a ilusão de totalidade, "alles" (tudo), esse tudo remete à língua Alemã no cotidiano das Gemeinde. Essa ilusão de totalidade contribui para a construção imaginária do imigrante e nela ele se reconhece. Assim, ao considerarmos a afirmação "alles war auf Deutsch zuerst" (tudo era em alemão), percebemos a importância da língua nas práticas sociais diárias desses sujeitos. Portanto, a língua cumpre um papel essencial: o de objeto simbólico de identificação. Isso significa que é pela preservação da língua que se cultivam as memórias, a cultura e o sentimento de pertencimento. Ao nos determos à teoria a partir dessa fala, podemos refletir sobre o processo de interpelação-identificação de Pêcheux (1997), que de acordo com o autor, passa pela língua, porque o indivíduo torna-se sujeito pela submissão à língua. Ainda, de acordo com o mesmo autor, a língua não é transparente e deve ser vista em seu funcionamento, nas práticas sociais e políticas.

Desse modo, na próxima sequência discursiva, não podemos considerar a língua Alemã apenas como um fato isolado das formas de subjetivação do sujeito e somente como estrutura gramatical, mas considerar a língua materializada nas práticas sociais em que ela significa a partir dos processos ideológicos que interpelam e subjetivam o sujeito imigrante a partir dos acontecimentos históricos do governo de Getúlio Vargas. Assim, podemos observar que o dizer do filho de imigrantes, em seu processo de subjetivação é interseccionado pelo domínio histórico das décadas de 1930 e 1940. Portanto, para significarmos e podermos interpretar, precisamos do sujeito e da língua na história.

Considerando essa perspectiva, podemos a partir da próxima sequência discursiva olhar as questões identitárias, as quais nos ajudam a pensar sobre as reflexões de Pêcheux (id,), no que se refere à construção da subjetividade a partir da língua, neste caso, a língua Alemã. A sequência é de um filho de imigrantes que nasceu em solo brasileiro, seus pais chegaram ao Brasil no final do século XIX e se estabeleceram nas terras oferecidas no Noroeste do Estado do Rio Grande do Sul. Apesar de se deslocarem e formar outras comunidades, longe do centro da imigração, os imigrantes e seus descendentes constituíam a sua Gemeinde (comunidades) e procuraram se manter unidos para sobreviverem e preservar seus laços identitários:

Sd2: Em casa, mesmo proibido, o pessoal falava em alemão, não sabíamos outra língua. Meus pais faleceram sem aprender o português. Era proibido os cultos em alemão, em português não, mas ninguém fazia em português, não tinha pastor na época.

Para entendermos essa $\mathrm{Sd}$, precisamos analisar os acontecimentos históricos e os processos ideológicos, como nos propõe Pêcheux (1997). Se analisarmos apenas a partir de uma leitura literal das palavras do descendente de imigrantes, podemos fazer uma leitura parcial, porque as palavras fora das condições de produção social não dão conta

coração, estrela e rodas e são decoradas com açúcar colorido e ajudam a ornamentar as mesas para as festas. Essa atividade é tão importante porque propicia momentos de união entre os familiares. Outro aspecto é que, na época, os pequenos agricultores não tinham muitos recursos financeiros e quase tudo era produzido pela família, no que se refere à alimentação. 
dos efeitos de sentido, precisamos considerar a língua em funcionamento e o sujeito na história para significar. Neste viés, este filho de imigrantes ao afirmar que falava a língua Alemã, mesmo esta sendo proibida, está se referindo ao momento histórico, no Brasil, das décadas de 1930 e 1940, cujo objetivo era criar uma política nacionalista para o país e, por isso, o Governo de Getúlio Vargas proíbe a fala de qualquer língua estrangeira e qualquer manifestação religiosa ou cultural que não fosse realizada na língua Portuguesa. Diante desse cenário, nos perguntamos como ficou a identidade do sujeito imigrante e seus descendentes, se conforme Pêcheux (id.), a subjetivação passa pela língua?

Fica claro que a língua nacional não lhes trazia nenhuma significação, o processo de subjetivação desses sujeitos não passava pela língua Portuguesa. Podemos entender isso quando ele se refere ao fato de que os cultos religiosos na língua Alemã eram proibidos, mas permitidos e obrigatórios em português, e sobre isso declara: "em português não, mas ninguém fazia em português, não tinha pastor na época”. Isso significa que essa era a língua do outro que precisavam aprender, mas não tinha grande valor para eles. Portanto, podemos perceber, pela fala do filho de imigrantes, que a língua proibida era a sua língua materna e esta tem função simbólica crucial na constituição dos sujeitos que saíram da Alemanha, porque a língua se encontra imbuída de valores e sentimentos identitários que os unem. Diante dessa identificação pela língua, a fala da $\mathrm{Sd} 2$ nos mostra, que, mesmo proibida, a língua materna para esses sujeitos continuava existindo, porque eles precisavam dela para ser, pois não sabiam ser de outro modo, essa era a língua que eles conheciam e que os constituíam. Em outras palavras, é somente no interior da FDIA que a subjetividade do imigrante alemão pode ser entendida.

Depreendemos que a subjetividade se dá na e pela língua e podemos observar isso na Sd2: "o pessoal falava em alemão, não sabíamos outra língua. Meus pais faleceram sem saber falar português". Desse modo, podemos dizer que os sujeitos, mesmo coibidos, mantinham a sua identificação atrelada à língua dentro de um convívio social restrito sob forte vigilância e porque os próprios imigrantes se vigiavam para não serem "pegos falando alemão”. A língua proibida era a língua que os constituía como sujeitos.

Ademais, a partir da $\mathrm{Sd} 2$ podemos pensar sobre a afirmação de Courtine (2009) sobre o intradiscurso como sendo um efeito do interdiscurso sobre si próprio. De modo que os pré-construídos elaborados sobre a importância da língua Alemã são absorvidos e esses se encadeiam na fala do sujeito e remetem a algumas evidências de sentido sobre essa língua e nelas o sujeito se reconhece como fonte de sentido. Portanto, é a partir dos saberes que se inscrevem na FDIA que o sujeito da $\mathrm{Sd} 2$ se reconhece e atribui significado à língua Alemã. E a partir dela seus laços sociais se estendiam basicamente aos seus familiares e conhecidos que dominavam a língua Alemã e a língua "do outro", a língua Portuguesa, não lhes era acessível, era muito difícil, ou até mesmo não queriam aprendê-la. Neste viés, poderíamos colocar outra questão: talvez, ao não falar a língua do outro, eles não queriam se inserir na cultura do outro, serem "fiéis" à sua cultura e a seus elementos identitários, porque sabiam que seus elementos identitários passavam pela língua e no momento em que esta é substituída, logo, são substituídos os elementos identitários por outros. Sendo assim, trata-se do fato de que os alemães e seus descendentes, como gesto de fidelidade continuaram falando a sua língua. Dessa forma, é pela FD que podemos refletir sobre as modalidades de assujeitamento, percebidas pelos pré-construídos, formulados nas sequências discursivas.

Nesta ótica, conforme Pêcheux (1997), o sujeito se reconhece como sujeito a partir da FD, em que se inscreve sob a ilusão de ser livre. Para o autor, todas as evidências, sejam de sentido ou da existência espontânea do sujeito são um efeito ideológico, "efeitos 
ideológicos em todos os discursos 8 ". Assim, "é a ideologia que fornece as evidências pelas quais 'todo mundo sabe', o que é um soldado". Se nos debruçarmos sobre os sujeitos imigrantes, há efeitos ideológicos pelos quais os sujeitos se reconhecem como imigrantes e parafraseando o autor, é a ideologia que fornece as evidências pelas quais "todo mundo sabe quem é um imigrante alemão". Entre as evidências podemos citar, a exemplo da Sd2, o fato de falar a língua Alemã, porque é evidente que "todo descendente de imigrante alemão fala a língua Alemã". Entretanto, nesta evidência temos mascarada a interpelação do sujeito. Sendo assim, é por meio das evidências do que querem dizer as palavras, mascaradas sob a transparência da linguagem, que se constitui o sentido das palavras nelas mesmas. A constituição do sentido se junta à constituição do sujeito através da interpelação, "a coletividade, como entidade pré-existente, que impõe sua marca ideológica a cada sujeito sob a forma de uma 'socialização' do indivíduo nas 'relações sociais' concebidas como relações intersubjetivas ${ }^{10 "}$ ". De acordo com o autor, trata-se da evidência do sujeito como único e insubstituível e idêntico a si mesmo, sob a ilusão de ser livre e dono do seu discurso. Contudo, para refletirmos sobre essas questões, é pertinente lembrarmos que o sentido de uma palavra é determinado pelas posições ideológicas que estão em jogo nos processos sócio-históricos, nos quais as palavras são (re)produzidas. Isso significa que as palavras mudam de sentido e adquirem efeitos de sentido, conforme a posição de quem as enuncia.

\section{Sprachmischung: língua e história}

Já discutimos, no decorrer desse estudo, que a língua assume materialidades distintas e nela sentidos são constituídos, silenciados e/ou excluídos a partir das condições de inscrição da língua na história. Assim, ao estudarmos a Sprachmischung, precisamos fazê-lo a partir das condições sócio-históricas em que ela se desenvolve. Isso significa que ao tratarmos sobre as questões dos imigrantes e seus descendentes no Rio Grande do Sul, fizemo-lo a partir dos acontecimentos históricos das décadas de 1930 e 1940. Isso porque esses sujeitos dialogam e respondem implicitamente a esses acontecimentos históricos, cuja marca principal é a interdição. Essa interdição produz efeitos de silenciamento a respeito dele próprio e da sua historicidade. Assim, temos a interdição do próprio sujeito pela língua, em virtude da proibição de falar a sua língua materna: a língua Alemã.

Deste modo, temos a língua Alemã, vista pelo Estado, como uma língua de outra nação e que precisa ser proibida, contudo, essa mesma língua representa para os imigrantes laços afetivos, que os constituem como sujeitos pelo processo de interpelação-identificação. Nas suas comunidades, a língua é um elemento simbólico essencial na construção do imaginário de identificação, como grupo de imigrantes alemães, e esse imaginário aparece na memória discursiva, ao falarem. Nesta ótica, a língua Alemã perpassa os três pilares (família, escola e igreja) que constituíram as Gemeinde (comunidades), mantendo o elo identitário dos grupos e as construções imaginárias de identificação entre eles. Contudo, é pertinente destacarmos que nas Gemeinde, em que a língua é preservada, não se trata da língua Alemã-padrão, mas de um dialeto, cuja estrutura é misturada com a língua Portuguesa. Essa mistura, a qual chamamos de Sprachmischung, deu origem a uma língua típica nas colônias, cujo entendimento, muitas vezes, é impossível para os cidadãos alemães. Portanto, ao trabalharmos com o conceito de Sprachmischung, estamos falando de uma variação dialetal que envolve a hibridação da língua Alemã com outra língua, no nosso caso, a língua Portuguesa, criando um léxico intermediário entre as duas línguas.

8 Ibidem, p.153.

9 Id., p.159.

10 Id. 155. 
Essa Sprachmischung permanece, principalmente, nas áreas rurais das regiões de colonização alemã. Segundo Ziegler (1996) "somit ist das Misturado als wichtigste Indiz die seit dem Beginn der Kolonisation in Rio Grande do Sul fortschreitende Urbanisierung $z$ u erachten, das deutlich auf eine Stadt-Land Differenz verweist ${ }^{11}{ }^{12}$ ". De acordo com o autor, nas regiões rurais, o misturado era usado nas tarefas diárias dos colonos, enquanto na cidade, muitos descendentes inseridos em situações sociais diferentes utilizavam a língua Portuguesa. Dessa forma, uma das características que diferem os descendentes das regiões rurais das regiões urbanizadas é a preservação ou não do dialeto alemão, chamado pelo autor de misturado. Segundo Ziegler (1996, p.85) a variante linguística assume dentro da sociedade uma função que se estende aos seus falantes, "sowie die vermittelten sozialen Funktionen, auch auf dem Sprecher und die verschiedenen kommunikativen Situationen besitzen $^{13}$ 14". Isso significa que os sujeitos ao falarem, assumem dentro da escala social um lugar e recebem um julgamento a partir da variante linguística usada.

Assim, ao tratarmos da Sprachmischung, consideramos as condições, em que ela se desenvolve. Sabemos que os imigrantes que vieram para o Brasil traziam na sua bagagem uma variante linguística menos culta do alemão vernacular. Esse não ficou fixo, antes estava em movimento. Deste modo, lembramos que a maioria dos colonos, no meio rural, lutando pelo autossustento, nem sempre tinha acesso a diferentes leituras e as palavras usadas nas suas práticas sociais restringiam-se ao modo peculiar de sua sobrevivência: a agricultura familiar. Além disso, com a implantação da política nacionalista, o uso da língua restringiu-se praticamente à conversação no ambiente familiar e no seu círculo de amizade. Isso significa que as palavras usadas no cotidiano diminuíram significativamente. Enquanto a língua Alemã padrão, utilizada na Alemanha e em toda a Europa, evoluiu, acompanhando todo o processo da industrialização vivido no continente europeu. Dessa forma, instaura-se um sentimento de inferioridade em relação ao dialeto falado pelos imigrantes e descendentes alemães no Brasil, cuja língua era classificada como "alemão errado". Esse sentimento de inferioridade era reforçado quando cidadãos alemães vinham para o Brasil e, muitas vezes, não compreendiam todas as palavras utilizadas pelos descendentes nas suas Gemeinde. Conforme Seyferth (2002), os cidadãos alemães cultos eram chamados de Neudeutscher (alemães novos) e eles demonstravam certa superioridade pelo domínio da língua, considerada "certa", e preferiam ficar na área urbana por causa da sua escolaridade, enquanto os colonos descendentes de imigrantes alemães eram inferiorizados pelo dialeto e pelo trabalho na área rural. Nesta ótica, os imigrantes instalados no Brasil há mais tempo apresentam uma língua peculiar, a Sprachmischung, resultado da mistura de duas línguas: o dialeto alemão, falado por eles, e a língua Portuguesa. Não se trata, portanto, de uma língua fixa, regida por normas pré-determinadas, antes uma língua em movimento. A partir da Sprachmischung, podemos trazer as reflexões de Orlandi (2002) sobre a língua fluida. De acordo com a autora, "a língua fluida seria aquela que não se deixa imobilizar nas redes dos sistemas e das fórmulas ${ }^{15}$ ".

11 ZIEGLER, Arne. Deutsche Sprache in Brasilien: Untersuchungen zum Sprachwandel und zum Sprachgebrauch der deutschstämmigen Brasilianer in Rio Grande do Sul. Essen: die Blaue Eule Verlag, 1996, p.85

12 Dessa forma, deve-se considerar a mistura de línguas como principal indício da progressiva urbanização, desde o início da colonização, a qual remete a clara diferença entre cidade e interior [a tradução é nossa].

13 Ididem, p. 85 .

14 Assim como intervém nas funções sociais, também aparecem sobre o falante e as diversas situações de comunicação [a tradução é nossa].

15 ORLANDI, Eni. Língua e conhecimento lingüístico: para uma história das ideias no Brasil. São Paulo: Cortez, 2002, p.66. 
Ao estudarmos a Sprachmischung, constatamos que não há apenas uma transferência de uma língua para outra, existe certo processo de germanização das palavras e essas palavras começam a fazer parte do vocabulário dos imigrantes nas suas práticas sociais diárias, como se elas "fossem" da língua Alemã. De acordo com Padre (2003), na Sprachmischung há uma tendência de utilizar substantivos da língua Portuguesa, inseridos em uma construção frasal em língua Alemã, como: rodoviária, chimir, potrea, tratoa, ônibus. Em relação aos verbos, a tendência é de organizá-los, acrescentando o sufixo "-ieren" no radical latino, a exemplo de avisierem, capinieren, combinieren, etc. Neste viés, ao analisarmos os exemplos, percebemos que se trata de uma germanização de palavras portuguesas, passando a integrar o vocabulário do dialeto alemão, mas que permanecem com a sua origem portuguesa, facilmente identificada. Temos outros exemplos retirados de trabalhos de Willems (1940), sobre a Sprachmischung: arrumierem (arrumar), wowo (vovô), Fakong (facão), Camoninhong (caminhão), Kadee (cadeia), Scharke (charque), Fumm (fumo) Maiyók (mandioca) Milye (milho), Mat (mate).

Ainda, para exemplificarmos como esse processo da Sprachmischung acontece nas práticas sociais desses sujeitos, traremos uma história relatada por um filho de descendente de imigrantes. O relato informal é de um senhor de 60 anos, agricultor, que mora na cidade de Carazinho/RS. A história é importante para ilustrarmos como algumas palavras de língua Portuguesa são usadas por eles e, muitas vezes, não se dão conta dessa Sprachmischung. De acordo com o senhor, sua família recebeu visita de alguns parentes da Alemanha aqui no Brasil. Na ocasião, o senhor os convidou para visitar a sua chácara, dizendo: "Dann fahren wir mit dem Caminhong bis die granja hin" (então nós vamos de caminhão até a granja). O parente da Alemanha indagou: "Wie bitte?" (como por favor?) O senhor que morava no Brasil, disse: "Aber was? Was haben Sie nicht verstan?" (Mas o quê? O que o senhor não entendeu?) E repetiu a frase: "Dann fahren wir mit dem Caminhong bis die granja hin" (então nós vamos de caminhão até a granja). Então, o outro senhor perguntou: "Aber was ist denn "Caminhong und Granja”? (Mas o que significa "caminhão e granja”?) Ao escutar a pergunta do seu parente, o narrador da nossa história se deu conta de que ele não dominava a língua Alemã padrão, como ele supunha, antes ele estava usando algumas palavras de origem portuguesa e germanizando-as. Dessa forma, essa rápida história serve para mostrarmos como a Sprachmischung está presente nas práticas sociais desses sujeitos e, ao mesmo tempo, percebemos que a língua Alemã não ficou estanque, antes está em movimento.

Ademais, a partir do fato narrado, podemos pensar o conceito de heteroglossia de Bakhtin (2004). De acordo com o autor, a realidade da língua é social e é nas práticas sociais que as palavras assumem efeitos de sentido, porque uma língua real está sujeita à hibridez e à exterioridade é constitutiva da língua. Portanto, a partir das condições sociais e históricas em que o senhor narrador se encontrava, ele acreditava "falar um bom alemão", porque com o seu círculo de amigos ele sempre falava essa língua, mas no momento em que são alteradas essas condições de produção do discurso é que ele se dá conta da sua Sprachmischung. Nesta ótica, não podemos analisar a Sprachmischung apenas pelo viés da língua enquanto sistema normativo de regras, antes precisamos considerar as condições de produção em que esse processo se desenvolveu. Além disso, o domínio da língua Alemã, mesmo no processo da Sprachmischung ${ }^{16}$, nos mostra como o processo da preservação da cultura e do elo identitário dos imigrantes e seus descendentes se mantiveram durante muitos anos.

16 Ziegler (1996), em seus estudos na obra: Deutsche Sprache in Brasilien: Untersuchungen zum Sprachwandel und zum Sprachgebrauch der deutschstämmigen Brasilianer in Rio Grande do Sul. Essen: die Blaue Eule Verlag, 1996, traz uma abordagem sobre diferentes autores, cujo enfoque foram as diferentes formas e estrutura de Sprachmischung. Nosso objetivo não é essa análise, queremos mostrar que essa Sprachmischung acontece nas práticas sociais dos imigrantes, está em movimento e permanece ainda hoje nas Gemeinde rurais do RS. 
Outra questão a ser considerada é que durante a campanha da implantação da 'língua nacional' não estavam em jogo apenas elementos linguísticos, tratava-se da presença de elementos políticos e ideológicos nesse processo. Em outras palavras, é pela 'língua nacional' que o governo varguista buscava convencer o povo para uma união, sob a égide de "vários povos unidos por uma só língua", temos aí a tentativa de uma fabricação de uma identidade coletiva. Segundo Seriót (2001) "o nacionalismo é a fabricação de uma identidade coletiva no plano imaginário ${ }^{17}$ ". Essa fabricação de uma identidade coletiva, nas décadas de 1930 e 1940, se utilizou da política da inclusão dos imigrantes pelo viés da língua, porém, ocorre o inverso, esses sujeitos foram excluídos e humilhados e isso deixou marcas em suas vidas.

Por isso, ao nos determos na história do Brasil sobre a língua Nacional, temos a implantação de uma política xenofóbica incisiva através da legislação específica na campanha nacionalista a partir do Decreto-Lei $\mathrm{n}^{\circ} 1545^{18}$, de 1939 . Esse decreto interfere diretamente na vida dos imigrantes alemães e seus descendentes, de modo que essas interferências são ainda hoje lembradas pela memória discursiva desses sujeitos, quando eles falam de si. O Estado implantou a língua Portuguesa como língua Nacional e tomou a cobrança dessa língua incisivamente nas áreas de colonização dos imigrantes. Sobre isso o jovem ${ }^{19}$, filho de descendentes imigrantes que mora em Arroio do Meio, diz:

Sd3: Na minha escola, onde eu estudava nós discutimos essa época de proibição da língua Alemã, que as pessoas não podiam falar alemão, quem falava apanhava, né. Ai pra eles não falar alemão ficava um guarda que ficava na sala, que passava de sala em sala, para ver se eles falavam alemão. Meu pai e minha mãe contam que naquela época tinham que ficar quietos, eles ficavam a aula inteira, ai quando o guarda saía, a professora retomava tudo em alemão pra explicar tudo de novo para a turma, porque a turma não tinha entendido nada. Ai, era bem ruim. Meu pai, minha mãe contam daquela época, eles não têm lembranças agradáveis da escola.

O jovem nos fala sobre fatos, aos quais ele não vivenciou, mas que permanecem na memória social desse grupo, seja por meio da escola ou por meio dos sujeitos que vivenciaram essa situação, a exemplo dos pais do jovem. A partir do que ele nos conta, podemos refletir novamente sobre a questão da interdição, em que os sujeitos, a partir de uma política linguística, precisam praticar uma língua $\mathrm{X}$ e, ao mesmo tempo, acontece a interdição para se comunicarem em outra língua Y. Já falamos que este fato inibiu significativamente a prática da língua Alemã, no domínio público e institucional, interrompendo as publicações da imprensa escrita, nas escolas e também no espaço privado. Isso significa que a interdição da língua Alemã aparece como um fato discursivo da ordem do silenciamento e do apagamento da língua e da memória, isto é, da unidade cultural dos imigrantes em detrimento do processo de nacionalização, como ele nos relata, "ai pra eles não falar alemão ficava um guarda que ficava na sala, que passava de sala em sala, para ver se eles falavam alemão", portanto, uma forte vigilância. A partir dessa fala, podemos refletir

17 SÉRIOT, Patrik. Linguística Nacional ou Linguística Nacionalista? In: Línguas - Instrumentos Linguísticos/ Universidade Estadual de Campinas. Pontes - Campus, SP: UNICAMP, 2001, p.54.

18 Artigo 15: "É proibido o uso de línguas estrangeiras nas repartições públicas, no recinto das casernas e durante o serviço militar” (REVISTA DO ENSINO, 1939, p. 136).

19 Aqui, também queremos esclarecer que a entrevista aconteceu em 2011, ano em que o jovem frequentava o segundo ano do Ensino Médio. 
sobre a reprodução das condições de produção da ideologia dominante pelo Aparelho Ideológico do Estado escolar (AIE escolar), conforme Althusser (1985). Para o autor, o AIE escolar reforça os mecanismos de controle da classe dominante, porque esse mecanismo de sujeição não se dá apenas nas ideias, mas nas práticas sociais diárias e o AIE escolar reproduz as condições de produção para a interdição da língua Alemã.

A sequência nos chama atenção porque a interdição da língua está presente na construção da identidade desses sujeitos, bem como na memória social desse grupo. Em outras palavras, não falar a língua Alemã implica em um silêncio que corrompe a identidade, porque eles deixam de dizer, não porque não sabem, mas porque estão impedidos, então, "o silêncio não é a ausência de palavras. Impor o silêncio não é calar o interlocutor, mas impedi-lo de sustentar outro discurso ${ }^{20}$ ". Nesta ótica, o silêncio trabalha na perspectiva da identificação dos sujeitos e é constitutivo do sujeito e da sua relação com a língua, seja a língua materna silenciada ou a língua nacional, em que ele se inscreve juridicamente como cidadão brasileiro. Essa relação densa entre os imigrantes alemães e sua língua com o período histórico das décadas de 1930 e 1940 está presente na memória social e aparece na própria constituição desse grupo. Contudo, apesar do controle e da interdição oficial no período do Estado Novo, a língua Alemã sobreviveu e ainda está presente em algumas comunidades de pequenos municípios. Porém, esses sujeitos não saíram imunes desse processo de nacionalização, essa interdição ecoa nas suas falas e na sua constituição e esta emerge pelo viés da memória social e na construção imaginária desse grupo, seja aquela que eles fazem de si mesmo ou aquela que os outros fazem deles.

Deste modo, o processo de nacionalização criou o discurso, em que alguns "podiam falar", os que tinham direito à voz eram aqueles que dominavam a língua Nacional e eles estavam autorizados a falar. Enquanto outros "deveriam calar", os que não tinham direito eram os imigrantes, visto que eles não "sabiam" falar a língua nacional, ao mesmo tempo, a eles é negado "o direito de serem sujeitos". Já que, conforme Pêcheux (1997), o sujeito se submete à língua para ser e significar-se, portanto, esses sujeitos não podiam ser, nem significar-se. Temos, conforme Orlandi (2007), "a interdição da inscrição do sujeito em formações discursivas determinadas, isto é, proíbem-se certos sentidos porque se impede o sujeito de ocupar certos lugares, certas posições ${ }^{21}$ ". Nesta perspectiva, o modo de ser do sujeito imigrante alemão é afetado, porque proíbe-se a sua língua e com ela os elementos que os constituem como sujeitos, procura-se impedir o sujeito de se inscrever e identificar-se como um imigrante, porque ele precisa criar uma nova forma de identificação: ser brasileiro. Para isso, ele precisa dominar a língua Portuguesa. Portanto, trata-se de um processo de identificação e, ao mesmo tempo, diz respeito às relações do sujeito com a língua do outro, cuja implantação passa por questões político-ideológicas e jurídicas.

Contudo, conforme observamos pelas sequências discursivas apresentadas no decorrer desta pesquisa, mesmo com forte proibição eles continuaram falando a sua língua materna, a língua Alemã. Para prosseguirmos nossa reflexão sobre a materialidade da língua, traremos a fala do jovem de 16 anos que nasceu no interior de Westfália/RS. Ele ainda conhece a língua de seus antepassados e ela está presente nas práticas sociais da sua Gemeinde, como ele nos conta:

20 ORLANDI, Eni Pucinelli. As formas do silêncio: no movimento dos sentidos. Campinas, SP: UNICAMP, 2007, p.102.

21 ORLANDI, Eni Pucinelli. As formas do silêncio: no movimento dos sentidos. Campinas, SP: UNICAMP, 2007, p. 104. 
Sd4: Bom, em casa, a gente fala alemão desde pequenos. A gente aprendeu alemão e português, os dois juntos. Em casa, a gente fala aquele Plattdeutsch ${ }^{22}$ e que nem na escola a gente fala Hochdeutsch ${ }^{23}$. Daí, a gente fala normal assim, qualquer coisa vem sempre direto assim o alemão, quase português, é... sempre normal. Na nossa comunidade, a maioria, todo mundo assim, fala alemão. Só que os jovens a maioria tão perdendo esse hábito.

A partir da fala do jovem, notamos que a língua que o constitui como sujeito é o Plattdeutsch como ele afirma, "bom, em casa, a gente fala alemão desde pequenos". Mesmo depois de três ou quatro gerações, desde o início da imigração alemã, essa variante linguística faz parte das suas práticas sociais e da sua Gemeinde. Para entendermos as condições, nas quais a língua sobrevive, lembrarmos o modo de organizações econômico-sociais, recreativas e culturais envolveu e funcionava quase por completo nas comunidades rurais das colônias alemãs. Isso significa que de certo modo essas comunidades conseguiam se manter sem necessitar da "ajuda externa", porque existiam nos centros das Gemeinde, tudo o que precisavam: a escola, a igreja e a venda. Esse último era importante porque compravam ou trocavam produtos dos quais necessitavam e essa organização comunitária permitiu que eles cultivassem a sua língua, sua cultura e sua história. De modo que essa vida comunitária se manteve e fez com que se estendesse até hoje essa forma de (con) viver, como o jovem entrevistado nos relata "na nossa comunidade, a maioria, todo mundo assim, fala alemão".

Embora, a nacionalização, promovida pelo Estado Novo, tenha abalado consideravelmente o modo social comunitário das Gemeinde dos imigrantes e seus descendentes, esse não foi totalmente apagado, conforme nos ilustra a sequência discursiva do jovem. Deste modo, as práticas do Governo Vargas com a Campanha de Nacionalização não conseguiram substituir totalmente a língua Alemã nas pequenas comunidades, em que ainda hoje existe a prática dessa variante, eminentemente oral: Sprachmischung. Como podemos perceber, quando nosso entrevistado diz "bom em casa, a gente fala alemão desde pequenos. A gente aprendeu alemão e português, os dois juntos". Isso significa que não podemos ignorar o fato de que a língua Portuguesa começou a ser aprendida pelas crianças nas escolas e elas começaram a usá-la, ao mesmo tempo, em que continuavam falando a língua Alemã, como forma de manter laços com suas origens e, sobretudo, essa era a língua que os constituía como sujeitos. Neste cenário, podemos pensar sobre as condições de produção em que acontece a Sprachmischung, porque aprenderam a falar as duas línguas concomitantemente, de forma que ao misturar o dialeto alemão e o português, eles se entendem do mesmo jeito, como ele afirma "a gente fala normal assim, qualquer coisa vem sempre direto assim o alemão, quase o português, é... sempre normal”. Essa afirmação ilustra a Sprachmischung, língua que o torna sujeito. A Sprachmischung é sua

22 Plattdeutsch (baixo-alemão) é uma variante linguística regional que pertence às regiões geograficamente mais baixas do norte da Alemanha e de partes vizinhas do norte da Europa. Devido ao seu uso e formas diferentes do Hochdeutsch assume na construção imaginária social um lugar inferiorizado, como se os sujeitos que dominam o dialeto também fossem inferiores socialmente.

23 Hochdeutsch também denominado Schrifftdeutsch é considerado o alemão gramatical. Essa denominação é atribuída à variante oficial do alemão, utilizada nas escolas e em todos os meios de comunicação. Essa língua oficial predomina sobre todos os dialetos. A diferença do Hochdeutsch para os diferentes dialetos encontrase no vocabulário, na sintaxe e na pronúncia. Assim como o Plattdeutsch, o Hochdeutsch é um dos grupos linguísticos da língua Alemã, contudo, não se encontra relacionada à nenhuma área específica, seja política ou geográfica, em que essa variante seja igual à oficial. Ressaltamos que, nas regiões de Hannover, encontra-se uma variante linguística coloquial que se assemelha ao Hochdeutsch. 
forma de identificação, porque não é mais somente pela língua Alemã que eles se reconhecem como sujeitos, mas pelo dialeto alemão (Plattdeutsch) misturado com a língua Portuguesa. Portanto, é nessa Sprachmischung que ele se reconhece como sujeito social. De acordo com Pêcheux (1997), a língua significa a partir dos processos ideológicos nos quais os sujeitos estão inseridos, porque não se pode dizer senão afetado pelo simbólico, porque os indivíduos tornam-se sujeitos pela submissão à língua.

Outro elemento, abordado pelo jovem na Sd 4, que merece nossa atenção é a questão do dialeto e do Hochdeutsch. Existe um lugar atribuído ao Plattdeutsch e outro ao Hochdeutsch e nesta diferença de falares está atribuído um juízo de valor aos seus falantes, classificando-os na estrutura social, de modo que o Hochdeutsch assume um lugar privilegiado e o Plattdeutsch, inferiorizado. Para aprofundarmos nossas reflexões e ilustrarmos como esse lugar interfere na vida das pessoas, traremos a fala de um filho de descendente de imigrantes alemães. Seus antepassados vieram por volta do início do século XIX e se instalaram na cidade de Venâncio Aires. Conforme ele nos conta, ele aprendeu o alemão gramatical e ensinou-o aos seus filhos:

Sd5: Eu me lembro, quando meus filhos eram menores, nós falávamos alemão com eles, o alemão padrão. Eu visitava meus tios e assim que eu falasse alemão padrão com meus filhos, eles ficavam quietos, não falavam mais. E diziam de imediato "Ja, das ist das falsches daitsch, das wir sprechen" (sim, este é o alemão errado, esse que nós falamos). Por mais que nós insistíssemos, não! Isso é uma opção nossa, eles estão acostumados com isso. Opção nossa, porque é o alemão mais compreendido, mas podiam falar o dialeto também. Na opção, nós optamos pelo padrão, até porque minha esposa falava o padrão. Mas os tios se fechavam, é uma pena.

A sequência discursiva chama atenção porque traz a visão preconceituosa que se tem sobre a variante linguística do dialeto alemão. O senhor nos relata uma situação familiar corriqueira, em que ele e sua família visitam seus tios. Na ocasião, eles falavam o dialeto alemão. Entretanto, essa forma de falar era silenciada no momento em que seus filhos, que sabiam falar somente o Hochdeutsch, se manifestavam, porque essa variante linguística não era dominada pelos tios. Sabemos que há uma variante linguística considerada correta e disso criou-se um imaginário social entre o "certo" e o "errado" entre falsches Daitsch ${ }^{24}$ e Hochdeutsch. A partir desse interdiscurso para o tio do entrevistado existe um "alemão certo", um falar ideal, mas para ele inalcançável, porque ele fala o falsches Daitsch. Aqui, podemos trazer a concepção de língua imaginária, que conforme Orlandi (2008), é aquela fixada na sua sistematização, neste caso, o Hochdeutsch. Enquanto aquela considerada "das falsches Daitsch" ( alemão errado), que não pode ser controlada pela sistematização, é a língua fluida e que traz traços sociais e históricos de seus sujeitos-falantes e se materializa nas práticas sociais. O dialeto alemão, usado nas práticas sociais das Gemeinde, deveria ser visto com respeito e não ser elemento simbólico de estratificação social, classificando os sujeitos em uma escala social e linguística inferiorizada, a qual eles assumem e nela se reconhecem, silenciando-se. Prova disso, é o silêncio do tio diante da fala das crianças, “mas os tios se fechavam”. Esse silêncio, conforme Orlandi (2002) é constitutivo e isso significa que eles se reconhecem, a partir de uma construção imaginária: a sua condição social e linguística inferiorizada. Portanto, não se tratam apenas de questões linguísticas,

24 Entendemos falsches Daitsch como uma variante dialetal que não tem prestígio, diferente do Hochdeutsch considerada como variante linguística culta da língua Alemã. 
mas também de questões histórico-sociais. Ademais, é pertinente destacarmos que a própria pronúncia do "das falsches Daitsch" (alemão errado) e não das "falsches Deutsch" denuncia essa condição de língua inferiorizada, porque parte-se do princípio de que há uma pronúncia correta. Na pronúncia, conforme a língua Alemã vernacular, a união das vogais "eu" resulta em /oi/, diferente daquela pronúncia do dialeto/ai/. Assim, o reconhecimento da pronúncia "errada" da palavra Daitsch, já demonstra essa estratificação e a partir dela a construção imaginária que fazem de si e dos outros, isto é, a de que o sobrinho e seus filhos falam o Hochdeutsch, portanto, ocupam um lugar social superior.

Outra questão pertinente nessa sequência discursiva que merece destaque é a "liberdade" do sujeito-falante. Essa liberdade está apoiada na ilusão dele ser a fonte de seus sentidos e ser o sujeito do seu próprio discurso, resultando em afirmações como ele reitera "nossa opção". Essa opção ocupa, conforme o imaginário social, um lugar privilegiado no domínio da variante linguística considerada correta: o Hochdeutsch. Embora o entrevistado reconheça a importância do dialeto alemão para as comunidades, podemos por meio de sua fala perceber que a escolha para a aprendizagem do Hochdeutsch está pautada na variante linguística considerada superior, cuja ideia é reforçada nas escolas. Apesar de o sujeito acreditar que essa é uma escolha dele e, por isso, ele afirma: "isso é uma opção nossa”, sabemos que se trata de um sujeito interpelado. Neste viés, podemos trazer as reflexões de Pêcheux (1997) do esquecimento $n^{\circ} 1$ e $n^{\circ} 2$, ao falar do sujeito assujeitado, em que o sujeito tem a ilusão de fazer suas próprias escolhas e como se elas tivessem origem em si mesmo e não estivessem ligadas aos saberes que o interpelam. Esses dois esquecimentos levam à ilusão discursiva do sujeito. Nesta ótica, temos presente os sentidos que o sujeito recebe como fonte de si e evidentes. Contudo, sabemos que esses sentidos que o sujeito recebe como "evidentes" passam pelo interdiscurso, cujos saberes estão inscritos na FD da classe dominante sobre a língua correta. No caso da sequência discursiva, os saberes que interpelam o sujeito estão pautados na construção imaginária que fazem da língua padrão, o Hochdeutsch. Essa variante linguística ocupa um lugar privilegiado na memória social e essa superioridade social é estendida aos seus falantes. Portanto, quando ele diz "opção nossa, porque o alemão é o alemão mais compreendido", temos presente um interdiscurso, cujos saberes remetem à variante linguística privilegiada, ao mesmo tempo, em que exclui a outra variante linguística considerada inferior, "das falsches Daitsch".

Ao nos determos em "mas podiam falar o dialeto também", observamos que eles também poderiam falar aquele alemão que não tem o mesmo reconhecimento, conforme o imaginário social. Esse imaginário social é constituído por pré-construídos que remetem ao preconceito linguístico e esse preconceito está presente no intradiscurso, "mas podiam falar o dialeto também". Nesta perspectiva, na fala do entrevistado ecoam vozes sociais do imaginário social, que estratificam e determinam a construção imaginária de sujeitos-falantes, como a da família do tio, evidenciado pelo silêncio e pela afirmação: " $j a$, das ist das falsches Daitsch, das wir sprechen" (sim, este é o alemão errado, esse que nós falamos). Dessa forma, podemos retomar novamente a questão trazida por Mey (2006), "a tua fala te denuncia ${ }^{25}$ ", porque a própria fala do sujeito o inscreve em uma ordem social inferiorizada, ao pronunciar a palavra "Daitsch". Essa pronúncia classifica o tio como um sujeito com pouco estudo e que não teve as mesmas condições como as de seu sobrinho, a de estudar e ter uma vida social melhor reconhecida e até mesmo remunerada.

Deste modo, ao voltarmos nossa atenção ao sujeito da enunciação da Sd5 que fala Hochdeutsch e analisarmos a sua defesa pela opção do Hochdeutsch, podemos depre-

$25 \mathrm{MEY}$ Jacob. Etnia, identidade e língua. In: Língua(gem) e identidade: elementos para uma discussão no campo aplicado/ Inês Signorini (org.). Campinas, SP: Mercado das Letras, 2006, p. 71. 
ender que essa variante foi escolhida por ser considerada superior no imaginário social, porém, na ilusão constitutiva da fonte de sentidos e origem de si mesmo, a escolha foi feita livremente. Essa evidência da ilusão discursiva do sujeito é expressa em: "opção nossa porque é o alemão mais compreendido", como se ele optasse livremente por essa variante linguística. Aqui, podemos trazer a ilusão do teatro da consciência de Pêcheux (1997), porque não somos sujeitos livres, mas sujeitos assujeitados aos saberes da FD que nos interpelam e com os quais nos identificamos. De acordo com o autor, o indivíduo é interpelado como sujeito livre e assim ele pode livremente submeter-se ao Sujeito Universal. Portanto, a partir da sua interpelação-identificação, ele se reconhece como sujeito social, tendo a ilusão de livremente fazer suas escolhas, como o senhor afirma "opção nossa". Ainda, ao dizer "mas podiam falar o dialeto também", nos leva a considerar que o dialeto é uma segunda opção, porque é uma língua que ocupa um lugar social inferiorizado. Prova disso, é o comportamento dos tios, relatado pelo sobrinho: "eu visitava meus tios e assim que eu falasse alemão padrão com meus filhos, eles ficavam quietos, não falavam mais. E diziam de imediato "Ja, das ist das falsches Daitsch, das wir sprechen" (sim, este é o alemão errado, esse que nós falamos) ”. Isso nos mostra como a estratificação linguística se dá nas práticas sociais na vida dos sujeitos. Enquanto o tio se silenciava, o sobrinho estava na condição de "escolher", porque ele dominava as duas variantes linguísticas e a partir da memória social, ele e sua esposa escolheram aquela que ocupa um lugar social superior e esta variante inscreve seus filhos em uma estrutura social considerada superior. Diante disso, explica-se o comportamento dos tios que perante tal condição silenciam.

De acordo com Orlandi (2007), "o silêncio é um trabalho de sentidos no confronto das diferentes formações discursivas em seus limites instáveis ${ }^{26 "}$. Isso significa que o silêncio não é a ausência de sentidos, antes é significativo. Ao voltarmos nossa atenção para a sequência discursiva temos uma variante linguística, considerada a correta, conforme as regras e as normas, estipula aquele que pode e tem o direto de falar porque domina o "Hochdeutsch", e aqueles que não a dominam, apenas sabem o "falsches Daitsch" ficam quietos. Portanto, eles estão fadados ao silêncio e era o que eles faziam, isto é, o silêncio é significativo. Isso porque o Hochdeutsch ocupa um lugar privilegiado no imaginário social e a partir deste são atribuídos lugares sociais aos sujeitos que falam uma ou outra variante. Portanto, essas duas variantes linguísticas ocupam lugares sociais distintos e a partir do domínio do Hochdeutsch ou Plattdeutsch atribui-se um lugar social aos sujeitos e sobre eles lançam-se olhares diferentes: o de superioridade ou inferioridade. Deste modo, podemos perceber que o interdiscurso trabalha saberes que colocam esses tios em uma condição social inferior. Conforme, já afirmarmos, isso está ligado à concepção de língua, segundo Orlandi (2002), a língua imaginária e a língua fluida, mas não apenas isso, estão presentes nessa construção imaginária elementos de ordem sócio-histórica, que são desconsiderados, como se eles não existissem.

\section{Considerações Finais}

A discussão apresentada nos permitiu pensar a relação entre sujeito, língua e história. Para que pudéssemos refletir sobre essa relação, procuramos compreender que o sujeito é social e historicamente constituído e que os elementos de identificação e de construção imaginária estão representados nas relações sociais e a partir delas eles se reconhecem e se identificam como sujeitos descendentes de alemães. Portanto, mostramos que esse processo de interpelação-identificação acontece pela captura plena do sujeito da enuncia-

26 ORLANDI, Eni Puccenelli. As formas do silêncio: no movimento dos sentidos. Campinas, SP: UNICAMP, 2007, p. 108. 
ção pelo Sujeito Universal da FDIA, cujo elemento simbólico essencial é a língua Alemã. Contudo, esse elemento simbólico é interseccionado pelas práticas políticas do governo Vargas, pautado pelas medidas do Decreto-Lei 1.545, de 1939. A partir desse Decreto existiu a proibição oficial da língua Alemã e de seus elementos culturais de identificação do grupo de imigrantes alemães. Essa proibição interfere diretamente nas condições de produção da preservação da língua Alemã, exigindo a língua Nacional. Esse acontecimento contribui para o processo da Sprachmischung, uma língua fluida que se materializa nas práticas sociais das Gemeinde (comunidades). Assim, nesta proibição, temos presentes elementos políticos e ideológicos que procuraram silenciar simbolicamente os elementos de identificação desse grupo e, ao mesmo tempo, um modo de controlar qualquer movimento político. Isso significou a interdição do sujeito pela língua e essa memória ainda hoje está presente nas falas dos sujeitos imigrantes e seus descendentes.

Referências Bibliográficas

ALTHUSSER, Louis. Aparelhos ideológicos de estado. Rio de Janeiro: Graal, 1985. BAKHTIN, Mikhail. Marxismo e Filosofia da Linguagem. São Paulo, Ed. Hucitec, 2004. Trad. Michel Lahud e Yara Frateschi.

COURTINE, Jean-Jacques. Análise do Discurso Político: o discurso comunista endereçado aos cristãos. São Paulo: EdUFSCar, 2009.

GAELZER, Vejane. Construções imaginárias e Memória Discursiva de imigrantes Alemães no Rio Grande do Sul. Tese de Doutorado (inédita), Porto Alegre, UFRGS, 2012. MEY, Jacob. Etnia, identidade e língua. In: Língua(gem) e identidade: elementos para uma discussão no campo aplicado/ Inês Signorini (org.). Campinas, SP: Mercado das Letras, 2006.

ORLANDI, Eni Puccinelli. As formas do silêncio: no movimento dos sentidos. Campinas, SP: UNICAMP, 2007.

. Língua e conhecimento lingüístico: para uma história das ideias no Brasil.

São Paulo: Cortez, 2002.

PÊCHEUX, Michel. Semântica e discurso: uma crítica à afirmação do óbvio. Campinas: Ed. Unicamp, 1997.

PRADE, Helga Guttenkunst. O linguajar do alemão gaúcho. In: Imigração alemã no Rio Grande do Sul: história, linguagem, educação. CUNHA,Jorge Luiz da, GATNER,Angelar (orgs.). Santa Maria: UFSM, 2003.

REVISTA DO ENSINO DO ESTADO DO RIO GRANDE DO SUL. v.1. n. 2. Porto Alegre, nov. de 1939. (ano I).

SEYFERTH, Giralda. Colonização, imigração e a questão racial no Brasil. Revista USP, 53, 2002.

SÉRIOT, Patrik. Linguística Nacional ou Linguística Nacionalista? In: Línguas - Instrumentos Linguísticos.Universidade Estadual de Campinas. Pontes - Campus, SP: UNICAMP, 2001.

WILLEMS, Emílio. Assimilação e populações marginais no Brasil. São Paulo: Nacional, 1940.

ZIEGLER, Arne. Deutsche Sprache in Brasilien: Untersuchungen zum Sprachwandel und zum Sprachgebrauch der deutschstämmigen Brasilianer in Rio Grande do Sul. Essen: die Blaue Eule Verlag, 1996. 